\title{
Assessing the Performance of Offshore Firms in Tunisia
}

\author{
Leila Baghdadi ${ }^{1+}$, Sonia Ben Kheder ${ }^{2}$, Hassen Arouri ${ }^{3}$ \\ ${ }^{1}$ Tunis Business School \\ ${ }^{2}$ Tunis Higher School of Economics and Trade (ESSECT) \\ ${ }^{3}$ National Centre for Statistics and Information, Sultanate of Oman
}

\begin{abstract}
This paper examines the performance of offshore firms in Tunisia for the period 2002 2014. Using firm-level data, we analyze the impact of offshoring on turnover, productivity, wages and firm survival. Overall, offshore firms perform better with respect to all of these indicators. However, in the specific case of offshore firms that export and import at the same time, called two-way offshoring, performance is weaker across the board compared to their onshore counterparts. Lower productivity of offshore firms engaged in both exporting and importing suggests that these firms are low performers and that they self-select the offshore regime to reduce their fixed costs associated with exporting. The survival analysis highlights an increased probability that these types of firms will exit the market once tariffs and tax exemption privileges end, usually after 10 years. Thus, incentives provided in the Tunisian Investment Code are primarily attracting firms in the lower rungs of global value chains.
\end{abstract}

Keywords: Exports, Fiscal incentives, Productivity, Multinational firms, Tunisia

JEL Classifications: F14, F23, L52

Received 17 December 2018, Revised 8 February 2019, Accepted 19 March 2019

+Corresponding Author: Leila Baghdadi

Associate Professor of Economics and World Trade Organization Chair Holder, BADEM Lab and World Trade Organization Chair, Tunis Business School, Université de Tunis, BP 65, Bir El Kassaa 2059, Tunisia, Tel: 0021679409409, E-mail: Leila.baghdadi@tbs.rnu.tn

Co-Author: Sonia Ben Kheder

Assistant Professor of Economics and World Trade Organization Chair Senior Fellow, BADEM Lab and World Trade Organization Chair, Tunis Business School, Université de Tunis, BP 65, Bir El Kassaa 2059, Tunisia; Assistant Professor of EconomicsESSEC de Tunis, Université de Tunis, 4 Rue Abou Zakaria El Hafsi, Montfleury 1089, Tunisia, E-mail: sonia.bkheder@gmail.com

Co-Author: Hassen Arouri

Senior Expert, National Centre for Statistics and Information, Sultanate of Oman, E-mail: hassen.arouri@gmail.com

Acknowledgements: The authors would like to thank the editor and the anonymous referee of the Journal of Economic Integration, three anonymous referees of the Economic Research Forum, Lionel Fontagné, Marion Jansen, Inmaculada Martinez-Zarzozo, Mustapha Kamel Nabli, Marcelo Olarreaga, Bob Rijkers, Chahir Zaki and participants to the fourth MENA Trade Workshop for their helpful comments. The authors are grateful to the Tunisian National Institute of Statistics for generously hosting them during this research. The authors gratefully acknowledge the financial and intellectual support of the research for this paper of the Economic Research Forum and the funding from the World Trade Organization Chair at Tunis Business School. 


\section{Introduction}

The Tunisian government has maintained an offshore regulatory regime to promote manufacturing export activity since 1972. This regime relies on a law (Law 72-38) that offers $100 \%$ exporting firms several tax and duty incentives. Offshore regimes are often used as part of broader economic reform packages to achieve higher levels of growth. The financial impact of Tunisia's offshore incentives is significant, and questions are now arising about their true benefits and whether it is in the country's economic interests to continue to pursue this strategy. According to the Economic Policy Analysis (ECOPA $\left.{ }^{1}\right)$ ) report (2012) commissioned by the International Finance Corporation, advantages granted to sole exporting firms under the offshore regime represented more than $50 \%$ of the total cost of fiscal and financial incentives for the period 2008 2011. Some economists argue that offshore regimes are an effective tool for initial economic improvement, but that they become ineffective once a country develops and opens up to trade. Although the offshore regime yielded significant results in the past, the policy debate in Tunisia today raises questions concerning its continued relevance and contribution to the Tunisian economy.

This paper is related to recent literature that uses firm-level data to explore the effects of foreign exposure on enterprises performance. Most of this research has focused on the relationship between exports and productivity in the manufacturing sector and shows that exporters are more productive than non-exporters. Bernard and Jensen (1995) wrote a seminal empirical work on this subject, using panel data from U.S manufacturing plants to demonstrate that exporting plants outperform non-exporting plants. Several subsequent studies built on that work, examining productivity differences between exporters and non-exporters, finding that exporting firms are more productive (Iacovone et al. 2012). These studies focus mainly on exporters in developed countries. Evidence for developing countries is still scarce, though there are some exceptions. Clerides et al. (1998) and Alvarez and Lopez (2005) examine Latin American developing countries, while Kraay (2002), Blalock and Gertler (2004), Yang and Mallick (2010) and Haidar (2012) focus on Asian developing countries.

Evidence about the relationship between imports and firms performance is much more scarce (Castellani et al. 2010, Kasahara and Lapham 2013). Nonetheless, some theoretical arguments predict a mutual causality between imports and better performance. With the emergence of new datasets that report information about imports, recent empirical work has been able to explore the relationship between productivity and export activity as well as productivity and import activity, comparing exporters, importers and exporters-importers to firms selling only to their domestic markets. This body of research generally concludes that firms that both export and import are the most productive, followed by importers, then exporters. Least productive are the companies

1) ECOPA is a consulting firm in economic analysis. 
that serve only the domestic market.

More recently, studies related to trade and firm performance have widened their scope to include firm characteristics other than productivity. For example, Serti et al. (2010) and Temouri et al. (2013) examined wages and profitability. However, due to a lack of data this type of analysis remains limited; much of it suffers from unobservable characteristics biases that lead to mixed results. There have been recent investigations into the relationship between firm survival and performance, as in Baldwin and Yan (2011) and Wagner (2013). The underlying hypothesis is that non-exporters are typically less efficient than exporters and thus are more likely to exit.

A topic closely related to this paper is the issue of exports and the performance of firms enjoying fiscal and financial privileges to promote exporting. Given the expansion of China's exports, many studies have examined the different policies implemented to encourage exports. Wang (2013) assesses the impact of Special Economic Zones (SEZ) created at the municipality level. He finds that the SEZ program increases foreign direct investment and wages, but to a lesser extent for zones created early. On the contrary, Dai et al. (2016) show that Chinese firm engaged in assembling tariff-exempted imported inputs into final goods for resale in foreign markets have a lower performance than other firms. Several studies have also assessed the case of offshore firms in Tunisia (ECOPA 2012, OECD 2013). These works investigate the offshore regime and highlight its main features but are not based on strong empirical analysis. Baghdadi (2015) investigated how firm type, including offshore firms, affects some aspects of the firm's performance.

This study offers a number of original contributions. First, there has not yet been a comprehensive investigation into the performance of offshore firms in Tunisia. Second, we use a unique comprehensive firm-level database that includes all existing firms in Tunisia. Therefore, we expect that results generated from our work will be more complete than results from previous studies. Third, the wealth of data in this database allows us to investigate all types of manufacturing firms, as well as services companies, i.e., all offshore and onshore firms, offshore and onshore firms that only export, and offshore and onshore exporting and importing firms. This is of great interest since services and imports are understudied. Fourth, the abundance of data makes it possible to examine not only productivity but other dimensions of exporter performance for which empirical evidence is usually lacking with respect to developing countries, e.g., turnover, wages and survival. Fifth, our work has policy implications since Tunisia's policy makers are continually examining the utility of the offshore regime and its benefits. This article seeks to contribute to the discussion by empirically investigating the efficiency of the offshore regime in Tunisia and its effect on the performance of Tunisian firms.

The central aim of this article is to examine the offshore regime in Tunisia and assess its overall contribution to Tunisian exports. In doing so, we aim to contribute to current policy debates around the effectiveness of Tunisia's export promotion strategy. We begin by describing 
the offshore regime in Tunisia in Section 2, providing an overview of statistics regarding offshore firms. In Section 3, we discuss the methodologies used to assess the performance of this regulatory regime and provide the results. Section 4 presents and interprets the findings of the survival analysis. We conclude in Section 5.

\section{Offshore Regime and Trade Policy in Tunisia}

After nearly 20 years of protectionism following Tunisian independence in 1956, and a policy based on import substitution, the country started to gradually change its trade policy and undertook reforms toward becoming a more open economy. Several free trade agreements were adopted as part of this transformation.

A major measure was the creation of an offshore regime to attract foreign direct investment for export-oriented production. The idea for the offshore regime emerged in the late $1960 \mathrm{~s}$, at a time when there was growing discontent with the socialist and collectivist policies that had been adopted by the Minister Ahmed Ben Salah. These policies were viewed by many as having contributed to a protracted economic and social crisis in Tunisia. This domestic context, combined with a growing global trend toward, and external pressure for economic liberalization, led to the eventual abandonment of socialist policies in favor of private initiatives. A new development strategy thus focused on promoting exports and implementing an offshore regime through the adoption of Law 72-38. This helped to accelerate Tunisia's economic liberalization, with some former import-substitution industries shifting to exports.

Tunisia's offshore regime, now regulated by the Investment Incentives Code (Code d'Incitations aux Investissements), offers several incentives to exporting companies, as described in Table 1.

This dual-track strategy garnered some success when it was implemented, as offshore firms employed low-skilled labor and increased exports of manufactured products. This era of "liberalization" witnessed a paradoxical mix of specific forms of state intervention combined with privatization and an opening of the economy to foreign investment and capital flows. At the same time, the period was characterized by growing political tensions and a severe balance of payments crisis that paved the way for the adoption of a Structural Adjustment Program in the late 1980s. The offshore regime increased Tunisia's participation in global value chains in recent decades (Organization for Economic Cooperation and Development (OECD) 2014), in the following sectors, among others: transport equipment; computer, electronic, electrical equipment, machinery and optical products, and textile, clothing, leather and footwear. However, the value-added content of these exports is low, which may be explained by the offshore firms' strategy assembling imported inputs for export. 
Table 1. Major incentives offered by offshore regime

\begin{tabular}{|c|c|c|c|c|}
\hline Incentive & Description & Update: Law 2006-80 & Update: Law 2007-70 & Update: Law 2010-58 \\
\hline $\begin{array}{l}\text { Tax exemptions on profit } \\
\text { and income }\end{array}$ & $\begin{array}{l}\text { Full exemption during } \\
\text { the first ten years of } \\
\text { activity, with a } \\
\text { 50-percent reduction } \\
\text { for the next ten years }\end{array}$ & $\begin{array}{l}2 / 3 \text { rds reduction on } \\
\text { income after January } \\
1,2008 \\
10 \% \text { tax on profits from } \\
\text { exports made after } \\
\text { January } 1,2008, \\
\text { except for firms } \\
\text { whose period of total } \\
\text { exemption (10 years) } \\
\text { has not expired }\end{array}$ & $\begin{array}{l}\text { 2/3rds reduction on } \\
\text { income after January } \\
1,2011 \\
10 \% \text { tax on profits from } \\
\text { exports made after } \\
\text { January } 1,2011, \\
\text { except for firms } \\
\text { whose period of total } \\
\text { exemption (10 years) } \\
\text { has not expired }\end{array}$ & $\begin{array}{l}\text { 2/3rds reduction on } \\
\text { income after January } \\
1,2012 \\
10 \% \text { tax on profits from } \\
\text { exports made after } \\
\text { January } 1,2012, \\
\text { except for firms } \\
\text { whose period of total } \\
\text { exemption (10 years) } \\
\text { has not expired }\end{array}$ \\
\hline
\end{tabular}

Exemption from customs

Total exemption

duties on imported

capital goods and inputs

Exemption of VAT and

Total exemption

consumption tax on

inputs and capital goods

(Note) We follow the classification of the National Institute of Statistics in Tunisia (Institut National de la Statistique), considering wholly exporting firms as offshore firms.

(Source) The Investment Incentives Code 1994

As Figure 1 shows, exports increased significantly during the period 2002 2014, and offshore firms contribute the largest share of total exports.

Figure 1. Evolution of exports in Tunisia 2002 2014

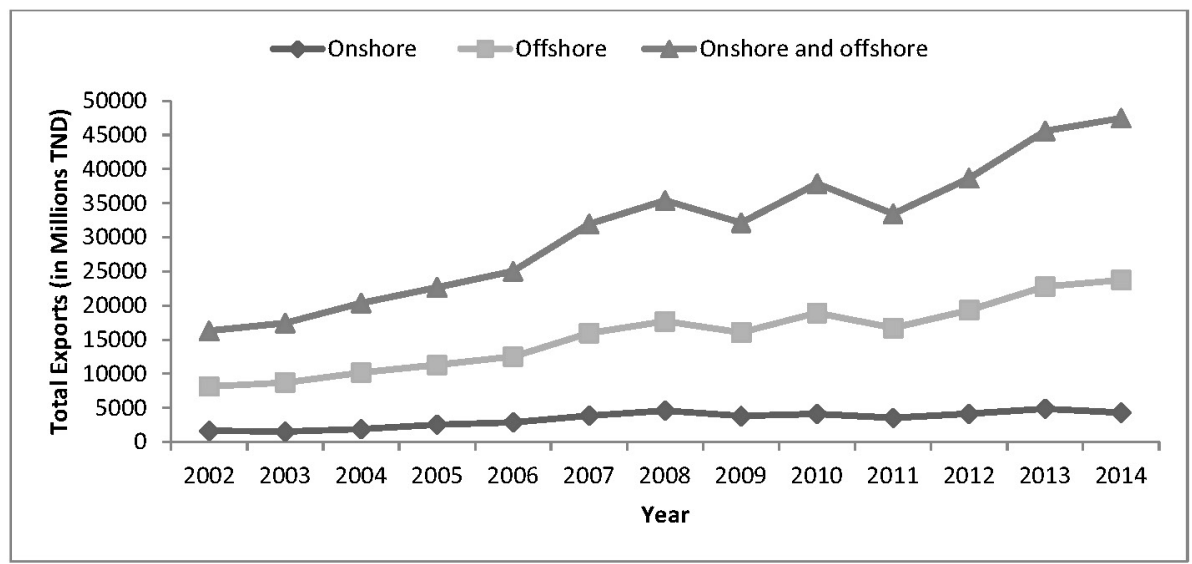

(Source) Authors calculations based on Tunisian Enterprise Survey data (Répertoire National des Entreprises) from the National Institute of Statistics.

We observe in Figure 2 that exports from offshore firms represent an average share of roughly $73.9 \%$ of total exports during the period, reaching peaks in 2003 and 2014 (79\% and 80\%, respectively) and a minimum in 2008 (69\%). These trends confirm that offshore firms, thanks to the incentives given, played a large role in Tunisian exports during throughout the last decades. 
Offshore firms' share of total turnover and profits is approximately $18 \%$ and $25.3 \%$, respectively. The evolution of the three indicators is similar. A gap between turnover and profits appeared in 2003 with a larger increase in profits relative to turnover.

Figure 2. Share of offshore firms in total values of exports, turnovers and profits

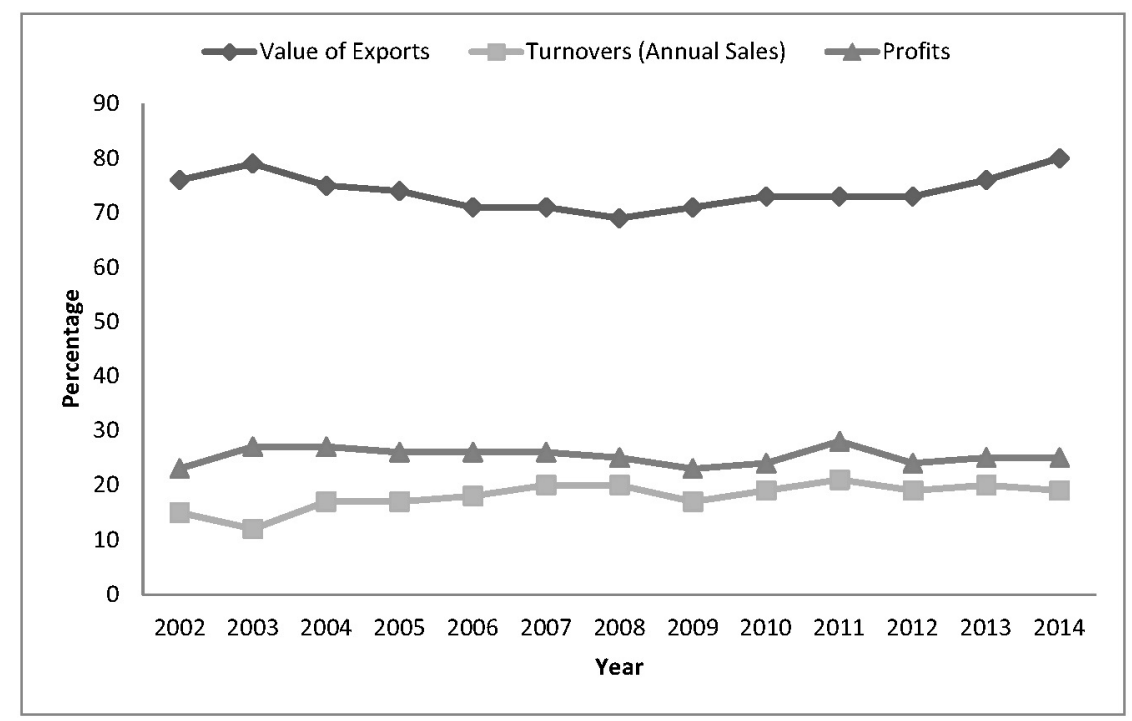

(Source) Authors' calculations based on Tunisian Enterprise Survey data (Répertoire National des Entreprises) from the National Institute of Statistics

Figure 3 below shows the share, in terms of number of firms and number of employees, represented by offshore firms in each sector. The largest share of offshore firms is found in the "transport equipment" manufacturing sector, where $38 \%$ of operating firms are offshore, with $88 \%$ of the employees in the sector. This next largest share, in terms of number of firms, is the "computer, electronic, electrical equipment, machinery and optical products" manufacturing sector, while the "textile, clothing, leather and footwear" manufacturing sector is the second largest in terms of the percentage of employees working for offshore firms in the sector. Since the offshore incentives were implemented nearly thirty years ago, the labor-intensive manufacturing sector has attracted the largest share of firms. Offshore firms appear to be less attracted by services sectors such as "Administration and support service activities," "Professional, scientific, technical services activities," "Information and communication services," "Wholesale, and retail trade," etc. These sectors are less amenable to offshoring than the Manufacturing sector. For example, it is difficult to offshore motor vehicle repairs. 
Figure 3. Share of offshore firms, by sector, 2002 2014

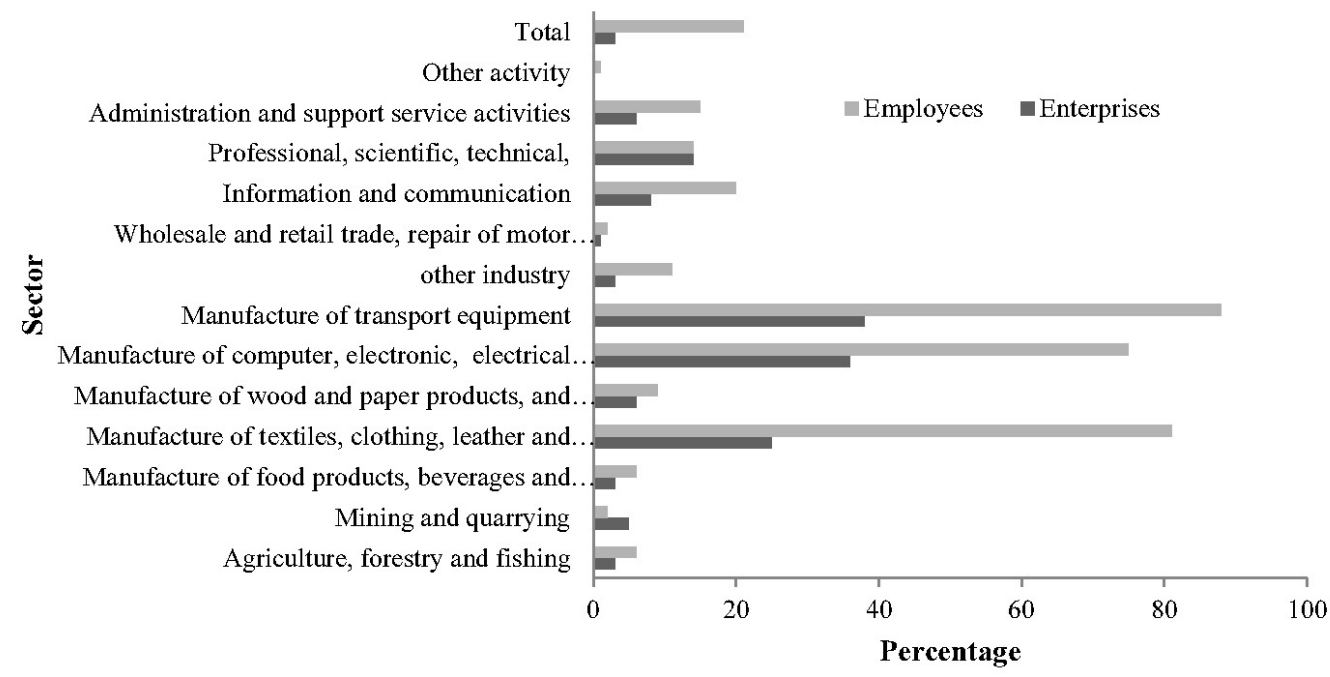

(Source) Authors' calculations based on Tunisian Enterprise Survey data (Répertoire National des Entreprises) from the National Institute of Statistics

The steady increase of Tunisian export flows registered during the last two decades is in part due to the creation of the offshore regime, which therefore could be considered relatively successful. However, with its tax holiday for offshore firms, the regime generated a dual track that has recently come under scrutiny. Questions have been raised about offshore firms' continued relevance. These tax privileges at a time when the economy in post-revolution Tunisia is difficult should be investigated.

\section{Methodologies}

We apply two methodologies to assess the overall effects of the Tunisian offshore regime. First, we test a baseline model to investigate whether being an offshore firm affects performance. We then estimate the offshore premium, i.e., the average percentage difference, in terms of turnover, productivity and wages, between offshore and onshore firms in the same sector and governorate (administrative division), in the same year,. Productivity is often seen as one of the most important indicators of the success of fiscal and financial policy, as noted by Rodrik (2004). Furthermore, studies often evaluate the performance of manufacturing firms through the impact of productivity and wages (Wang 2013, Dai, Maitra, and Yu 2016). We also consider turnover as way to capture the sales performance of firms. We estimate the offshore premium based on three categories of trade statuses: (i) offshore versus onshore, (ii) offshore firms engaged solely in exporting (referred to as "offshore exporters") versus onshore firms that only 
export, and (iii) offshore firms that both export and import (called offshore exporters and importers) versus onshore firms that export and import.

\section{A. Data used2)}

This study uses data collected by the National Institute of Statistics in Tunisia (Institut National de la Statistique), aggregated within the Tunisian registry of firms, called the Répertoire National des Entreprises (RNE). The RNE uses information from various sources: the Tunisian Customs, the Tunisian Ministry of Finance, the Tunisian Investment Promotion Agency (Agence de Promotion de l'Industrie et de l'Innovation) and the social security fund (Caisse Nationale de la Sécurité Sociale-CNSS). A detailed description of the RNE is presented in Rijkers et al. (2014). An advantage of the Répertoire data is that it accounts for all enterprises in Tunisia and covers a relatively long period of time. We only include private firms in our sample. Thus, this database contains information on all registered private firms including the number of employees, the firm's age, and its main activity, as well as its trade regime categorization (i.e., offshore or onshore). This allows us to examine the dynamics of both categories of firms, which are often not covered by other surveys, and especially to assess the impact of the preferential offshore regime by estimating the offshore premium. Regarding productivity, the RNE data was merged with turnover data from the Tunisian Ministry of Finance. Finally, the RNE database allows us to track the exit and entry of firms over time, which is valuable for conducting our survival analysis (see Section 4). It is important to bear in mind that this database covers firms, but not establishments or plant affiliated to parent firm. We also exclude firms that report less than one employee in order to take into account only active firms. Indeed, the National Institute of Statistics found that $8 \%$ of firms registered as "self-employed" (reporting no employees) are inactive survivors usually called "falsely active" or "zombie firms." We consider the period 2002 2014 for our analysis. All variables are described in Appendix 1. Descriptive statistics are presented in Appendix 2.

\section{B. Offshore premium}

\section{Baseline specification}

To investigate the impact of trade status on the various performance indicators, we use panel data for period 2002 2014 and estimate the following equation:

$$
\ln X_{i t}=\alpha+\alpha_{1} T S_{i}+\alpha_{2} V_{i t}+\mu_{k}+\varepsilon_{j}+\varepsilon_{t}+\eta_{i t}
$$

2) Estimations were conducted at the National Institute of Statistics as the data are not public. 
$X_{i t}$ is the performance of firm $i$ with respect to the variable of interest, in year $t$. Depending on the specification, the variable represents either annual turnover, gross output per worker or average annual wage levels per worker. $T S_{i}$ is a dummy variable indicating the time-invariant trade status of firm $i$ (offshore or onshore, offshore-only exporter or onshore-only exporter, offshore exporter and importer or onshore exporter and importer). $V_{i t}$ is a vector of control variables. In addition to the size variable that has been identified in the literature, $V_{i t}$ includes a foreign ownership dummy variable, and one that controls for tax evasion. Following Rijkers, Arouri, and Baghdadi (2017), the tax evasion variable takes a value of 1 if we detect anomalies in the firm's reporting. For instance, we assume the firm is most likely evading taxes if sales reported to the social security administration are lower than (i) the wage bill reported to the social security administration (ii) total exports or (iii) total imports recorded in customs transactions data. Indeed, Rijkers, Arouri, and Baghdadi (2017) show evidence of tax evasion from some Tunisian companies, especially those politically connected to former Tunisian President Ben Ali and his family. Therefore, controlling for tax evasion is important since it could affect the performance variables of interest.

We did not include firm age because age and size are endogenous. Since Tunisia is divided into twenty-four governorates corresponding to territorial administrations that have time-invariant characteristics in common, we introduce $\mu_{k}$ to control for governorate-specific effects, thus capturing some effect of the policy of regional development implemented in Tunisia. Finally, $\varepsilon_{j}$ is a vector of dummies controlling for effects specific to a sector (based on a 2-digit classification scheme), $\varepsilon_{t}$ is a vector of year dummies and $\eta_{i t}$ is the error term.

Table 2 below reports our results. Column (2a) shows our findings when Trade Status refers to all offshore firms. Column (2b) displays results of the estimation when Trade Status refers only to offshore exporting firms while Column (2c) shows the results of the estimation when Trade Status refers to offshore exporting and importing firms.

Our findings indicate that being an offshore firm leads to greater turnover, higher productivity and higher wages than being an onshore firm. Regarding the control variables, all indicators increase with the size of firms. Furthermore, evading taxes reduces all performance indicators. This finding makes sense since firms that evade taxes understate performance in order to pay fewer taxes. Finally, these results show a positive relationship between foreign ownership and firm performance.

Column (2b) shows similar results when only those firms engaged in exporting are studied, compared to the results in Column (2a) that cover all offshore firms, with few exceptions. Larger firms appear to have lower productivity when only exporting firms are considered. Tax evasion is consistent with higher average wages, which may indicate that exporting firms that may be attempting to evade taxes are reporting higher wages.

Turning to Column 2c, our findings show that offshore firms engaged in both importing 
Table 2. Performance of offshore firms

\begin{tabular}{|c|c|c|c|c|}
\hline & & $\begin{array}{l}\text { All firms } \\
\text { (2a) }\end{array}$ & $\begin{array}{l}\text { Only Exporter } \\
\text { (2b) }\end{array}$ & $\begin{array}{l}\text { Exporter and Importer } \\
\qquad(2 \mathrm{c})\end{array}$ \\
\hline \multirow[t]{8}{*}{ Ln Turnover } & Trade Status & $0.373 * * *$ & $0.136 * * *$ & $-0.314 * * *$ \\
\hline & & $(0.009)$ & $(0.014)$ & $(0.016)$ \\
\hline & LnEmployees (size) & $1.313 * * *$ & $0.854 * * *$ & $0.892 * * *$ \\
\hline & & $(0.002)$ & $(0.005)$ & $(0.004)$ \\
\hline & Evasion & $-1.385^{* * *}$ & $-1.867 * * *$ & $-0.605 * * *$ \\
\hline & & $(0.008)$ & $(0.025)$ & $(0.014)$ \\
\hline & Foreign Ownership & $0.212 * * *$ & $0.162 * * *$ & $0.189 * * *$ \\
\hline & & $(0.011)$ & $(0.018)$ & $(0.015)$ \\
\hline \multirow[t]{8}{*}{ Ln Productivity } & Trade Status & $0.391 * * *$ & $0.146^{* * *}$ & $-0.301 * * *$ \\
\hline & & $(0.009)$ & $(0.014)$ & $(0.016)$ \\
\hline & LnEmployees (size) & $0.135 * * *$ & $-0.305^{* * *}$ & $-0.185^{* * *}$ \\
\hline & & $(0.002)$ & $(0.005)$ & $(0.004)$ \\
\hline & Evasion & $-1.344 * * *$ & $-1.811^{* * *}$ & $-0.591 * * *$ \\
\hline & & $(0.008)$ & $(0.025)$ & $(0.014)$ \\
\hline & Foreign Ownership & $0.230 * * *$ & $0.178 * * *$ & $0.189 * * *$ \\
\hline & & $(0.01)$ & $(0.017)$ & $(0.015)$ \\
\hline \multirow[t]{8}{*}{ Ln Average Wage } & Trade Status & $0.021 * * *$ & $0.094 * * *$ & $-0.216^{* * *}$ \\
\hline & & $(0.003)$ & $(0.007)$ & $(0.007)$ \\
\hline & LnEmployees (size) & $0.136^{* * *}$ & $0.071 * * *$ & $0.080 * * *$ \\
\hline & & $(0.001)$ & $(0.003)$ & $(0.002)$ \\
\hline & Evasion & $-0.009 * * *$ & $0.059 * * *$ & $-0.059^{* * *}$ \\
\hline & & $(0.003)$ & $(0.013)$ & $(0.006)$ \\
\hline & Foreign Ownership & $0.239 * * *$ & $0.230 * * *$ & $0.151 * * *$ \\
\hline & & $(0.004)$ & $(0.009)$ & $(0.006)$ \\
\hline $\begin{array}{l}\text { Number of } \\
\text { Observations }\end{array}$ & & $7,014,836$ & 104,405 & 72,081 \\
\hline
\end{tabular}

(Note) $* * * p<0.01 ; * * p<0.05 ; * p<0.1$

Governorate, year and sector fixed effects are included in all regressions

and exporting have lower performance than their onshore two-way trading counterparts. This contradicts previous findings concerning other categories of offshore firms that showed a positive impact on performance. The control variables for two-way trading firms are similar to the results in Columns (2a) and (2b). As in Column (2a), the coefficient of the size variable is negative and statistically significant in the productivity specification. However, tax evasion has the same negative impact on average wages as in Column (2a) and is opposite in sign to the one in Column (2b). 


\section{Offshore premium specification}

In our investigation of the offshore premium, we adopt a similar methodology to the approach employed in much of the recent literature on trade premia. A trade premium is defined as the percentage differences, ceteris paribus, in firm characteristics between exporting and non-exporting companies, as in Haidar (2012) and Wagner (2012). The methodology involves two steps. Differences in the levels of the variables of interest between exporting and non-exporting companies are documented in the first step. In the second step, the trade premium is estimated for each variable of interest through a linear regression of the $\log$ of the variable on multiple control variables.

However, while those recent studies show new evidence regarding trade benefits by comparing exporting and non-exporting companies, this research specifically examines the impact of the offshore regime by comparing offshore and onshore companies. Here, we focus on what we call the "offshore premium," defined as the percentage differences, ceteris paribus, in firm characteristics between offshore and onshore companies. First, we investigate whether a difference exists between offshore and onshore firms regarding turnover, productivity and wages. We then estimate for each firm $i$ at each year the offshore premium, using the equation below:

$$
\ln X_{i}=\alpha_{0}+\beta T S_{i}+\gamma V_{i}+\mu_{k}+\varepsilon_{j}+\eta_{i}
$$

where the variables are similar to those used in Equation (1) but are year-specific. More precisely, $X_{i}$ is the performance indicator (annual turnover, gross output per worker or average annual wage levels per worker, depending on the specification) for firm $i . T S_{i}$ is the dummy variable representing the trade status of firm $i$ (offshore or onshore, offshore-only exporter or onshore-only exporter, offshore exporter and importer or onshore exporter and importer, depending on the specification). $V_{i}$ is the vector of variables controlling for size, foreign ownership and tax evasion. As described in Table 1, there is no condition on ownerships for offshore firms. They can be foreign or local owned. $\mu_{k}$ stands for governorate-specific effects, $\varepsilon_{j}$ controls for sector and $\eta_{i}$ is the error term.

\section{Results}

The following presents results for premia computed during the period 2002 2014 for each category of offshore firms, i.e., all offshore firms, offshore solely exporters and offshore exporters and importers, in Tables 3, 4 and 5, respectively. Table 3 shows that offshore firms have a premium in all indicators compared to their onshore counterparts when the average percentage differences between offshore and onshore firms are compared within the same sector and governorate. Turnover and productivity of offshore firms are, on average, $40.78 \%$ and $42.21 \%$ higher than for onshore counterparts, respectively. The shock of the financial crisis of 2008 2009 


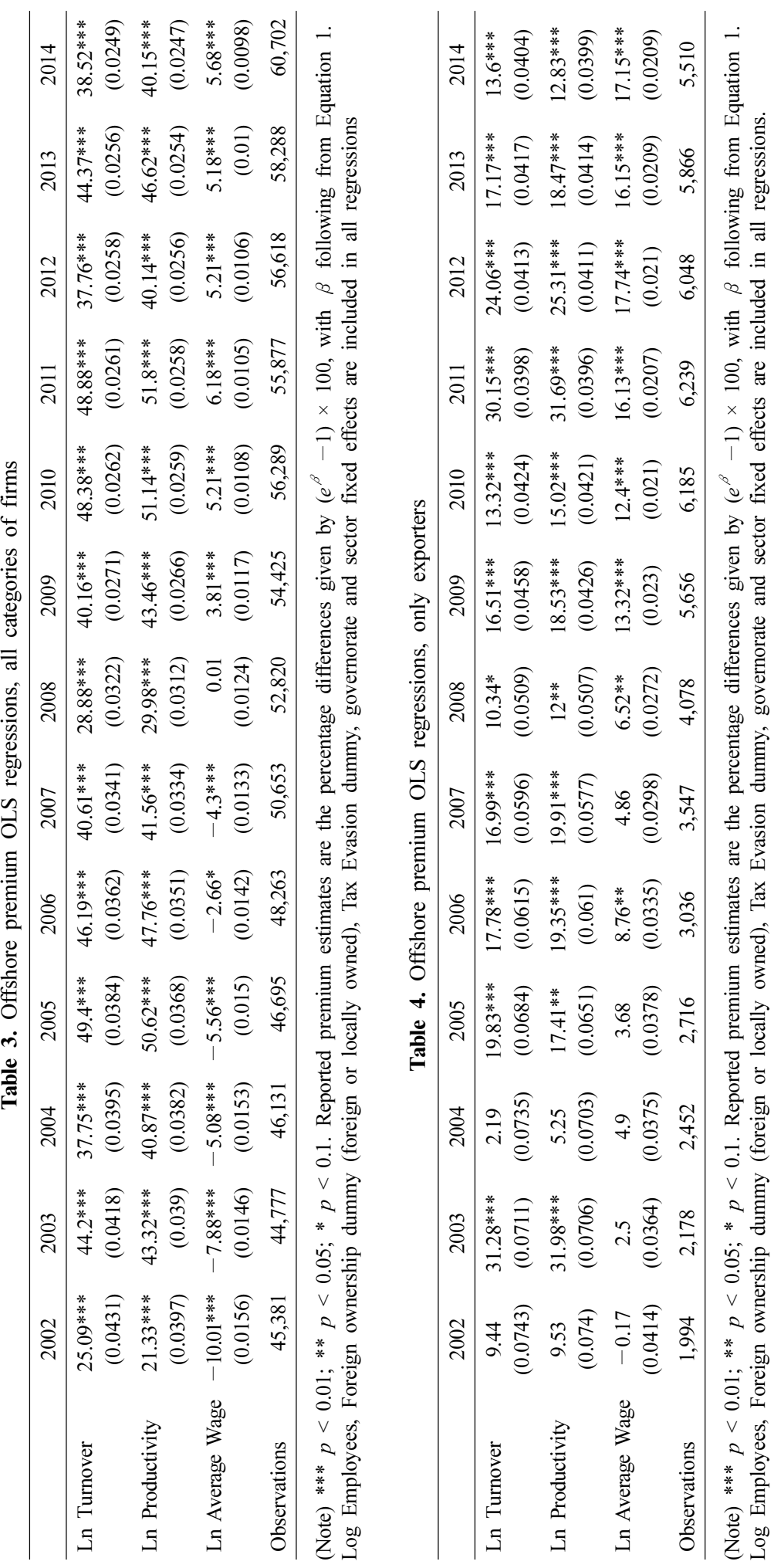




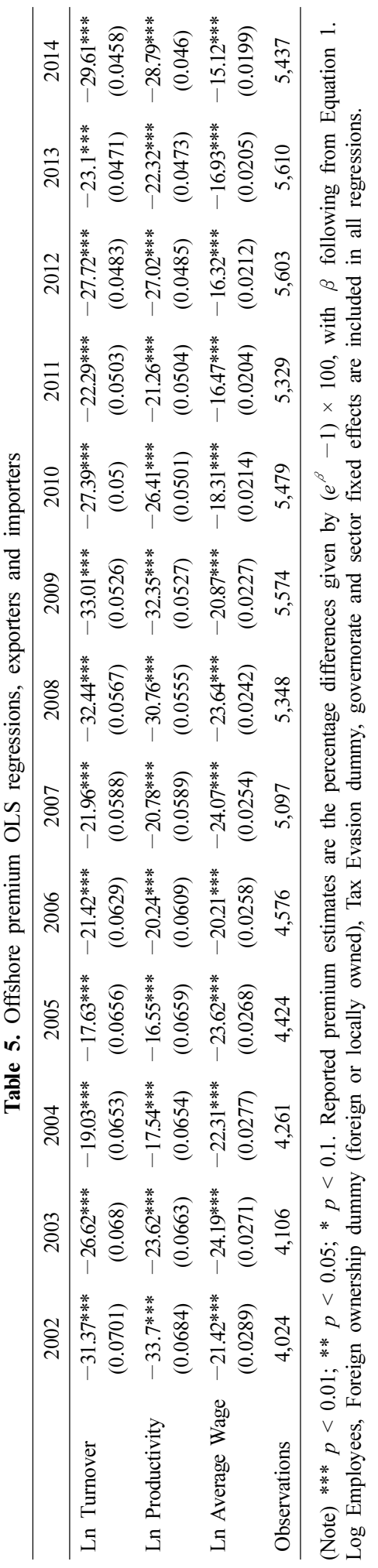


negatively impacted the offshore premium for all performance indicators other than average wages. Wages for offshore firms were initially lower than for onshore firms, until 2008 when they become higher. ${ }^{3)}$

Offshore firms are required by law to export their products. Therefore, it is more accurate to estimate their performance compared to a sub-sample of comparable onshore firms, i.e., exporting onshore firms. Therefore, we estimate the offshore exporter premium in a second step. In a third step, we run regressions on two sub-samples, i.e., offshore-only exporting firms and offshore exporting and importing firms. Table 4 displays the differences between offshore exporting firms and their onshore counterparts. It shows an offshore premium for exporting firms, defined as the average percentage difference between offshore and onshore firms that are engaged in exporting, within the same sector and governorate, during the same year. Similar to the offshore premia shown in Table 3, we observe an exporter offshore premia for all indicators. Nevertheless, these premia are lower than the offshore premia shown in Table 3, except for the premium associated with average wage after 2008. For instance, turnover of offshore exporters in 2014 is $13.6 \%$ higher than the turnover of onshore exporting firms, whereas the offshore premium in turnover based on all firms is $38.52 \%$. In 2008, performance indicators declined but soon returned to their previous levels. One exception is the wage premium of offshore exporting firms, which is not significant prior to 2008, except in 2006, and becomes positive afterwards. For example, offshore exporters paid their workers on average $17.15 \%$ more than onshore exporters in 2014.

One rationale for the tariff-free policy set for offshore firms is to promote greater inclusion in global value chains (GVCs). Thus, it is also important to compare two-way trading firms offshore, i.e., offshore firms that export and import at the same time, to two-way trading firms onshore. Table 5 reports results of estimates calculated for exporting and importing firms. The premia in this category of offshore firms show some differences compared to the previous two categories. Turnover for offshore two-way trading firms is, on average, $25.66 \%$ weaker than for onshore two-way trading firms. Productivity and wages are about $24.72 \%$ and $20.27 \%$ weaker, respectively, for offshore two-way trading firms.

These results might reflect that within this category, offshore firms are concentrated in relatively more labor-intensive industries than their onshore counterparts. The fact that labor productivity remains relatively low can attest to offshore firms' failure to rise higher on the quality ladder. These results are consistent with Dai, Maitra, and Yu (2016) who show that processing firms (e.g., firms that assemble and resell tariff-exempted imported inputs in foreign markets) are less productive and pay lower wages than non-processing exporters and non-exporters in China. Processing firms assemble tariff-exempted imported inputs into final goods and export

3) We test the robustness of our results by looking at the effects of the 2008 2009 financial crises on firms' performance and by controlling for restrictions entry. Results are presented in Appendix 3. 
them to foreign markets. In this respect, they are similar to two-way offshore trading firms in Tunisia. Dai, Maitra, and Yu (2016) provide two explanations for the low performance of processing firms. First, processing exports is associated with lower fixed costs of exporting as (i) foreign buyers are responsible for distribution, thus processing firms have lower distribution costs, (ii) foreign buyers supply the know-how, which lowers investment in research and development, (iii) parts and inputs are received without payments. Second, tariffs and tax exemptions reduce fixed costs. Therefore, processing firms self-select into tax and tariff-exempted processing regimes because they are otherwise not able to cover export-related fixed costs. Similarly, an offshore regime mainly attracts firms with low productivity. Incentives do not seem to be the best mechanism to incentivize offshore firms to play a more important role in GVCs since these firms are concentrated on the lower rungs of GVCs. As suggested by an OECD report in 2014, offshore firms in Tunisia are mainly assembling imported inputs to export them afterwards. Contrary to the standard objectives associated with establishing an offshore regime, tax exemptions are captured by foreign firms but are not beneficial to Tunisian competitiveness. This result questions the efficiency of generous benefits given by the Tunisian Investment Code.

Figures 4 through 6 sum up the evolution of performance indicator premia for the three categories of offshore firms. Figure 4 illustrates the offshore premium for turnover. Turnover of all offshore firms appear to be $25 \%$ to $50 \%$ higher than turnover of onshore firms. However, while the offshore exporters' premium ranges from $9 \%$ to $25 \%$, offshore importers and exporters show a turnover that is $17 \%$ to $30 \%$ below their onshore counterparts. Furthermore, Figure 4 clearly shows a decrease in turnover premia of offshore firms in 2008.

Figure 4. Turnover premium by trade status

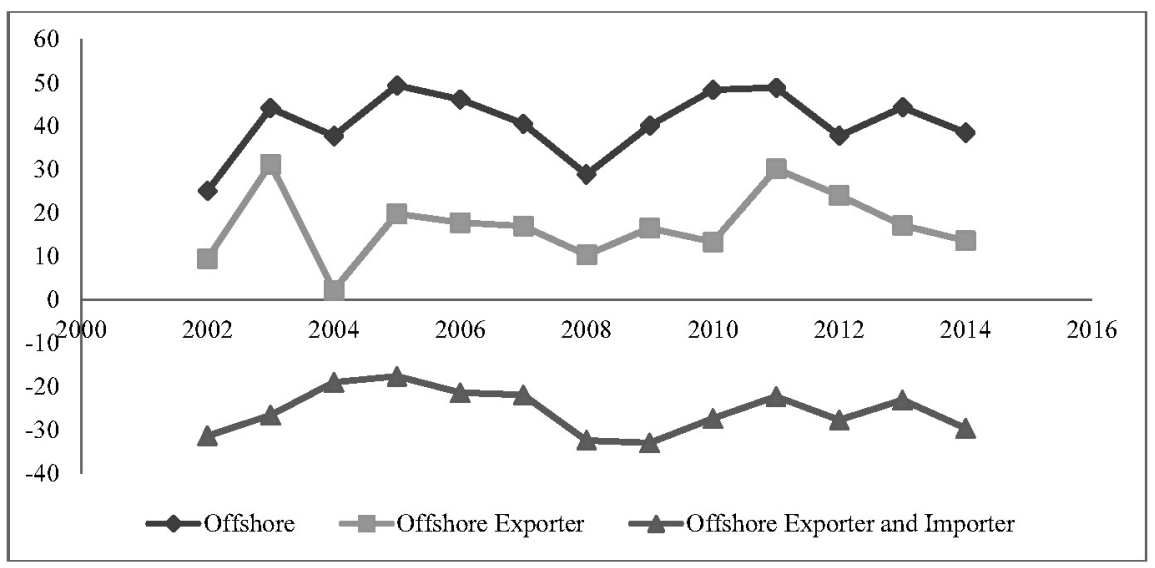

(Source) Authors calculations based on Tunisian Enterprise Survey data (Répertoire National des Entreprises) from the National Institute of Statistics 
One possible explanation is the drop in external demand, primarily from the European market, following the 2008 financial crises. These firms appeared to recover beginning in 2009 . We also observe a decline of turnover premia of offshore exporters starting in 2011, probably reflecting the economic consequences of the 2011 revolts (the "Arab Spring") that occurred in Tunisia and lead to a change in the political regime.

Figure 5. Productivity premium by trade status

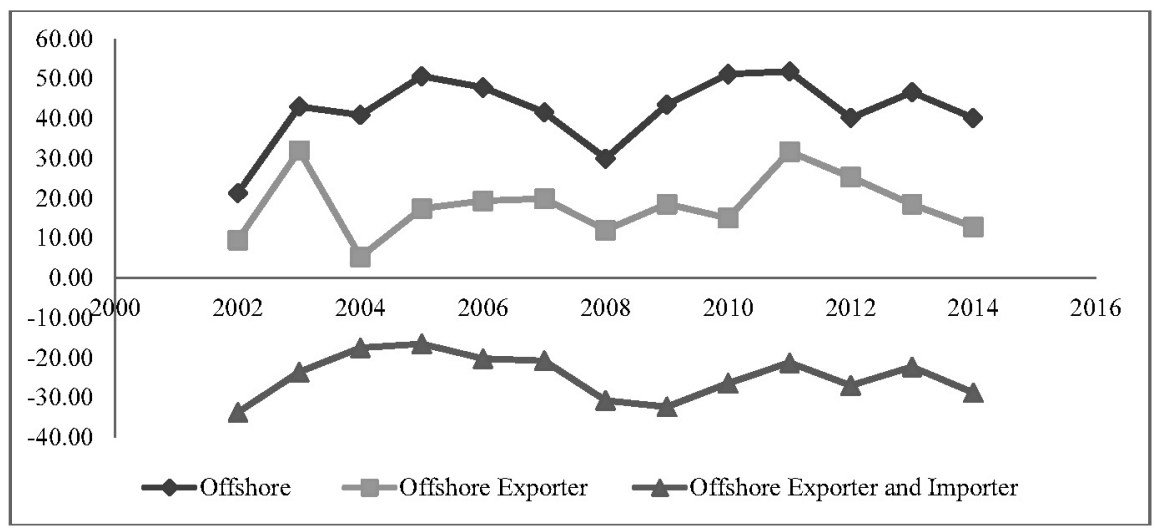

(Source) Authors calculations based on Tunisian Enterprise Survey data (Répertoire National des Entreprises) from the National Institute of Statistics

Figure 5 displays the productivity premium by trade status. The trend is the same as with the turnover premium. The productivity of offshore firms as a whole and the productivity of offshore exporters is higher than the productivity of their onshore counterparts. Nonetheless, the productivity of two-way trading offshore firms is $16 \%$ to $33 \%$ lower than productivity of two-way trading onshore firms, which supports the idea that offshore firms are more labor intensive than onshore firms. Similar to Figure 4, we observe a decline in 2008 in the productivity premia of all categories of offshore firms.

Figure 6 shows a significant increase in the wage premium after 2008 for all offshore relative to all onshore firms, and between offshore exporters and onshore exporters. The figure highlights the lower average wages paid by offshore firms engaged in both exporting and importing. 
Figure 6. Average wage premium by trade status

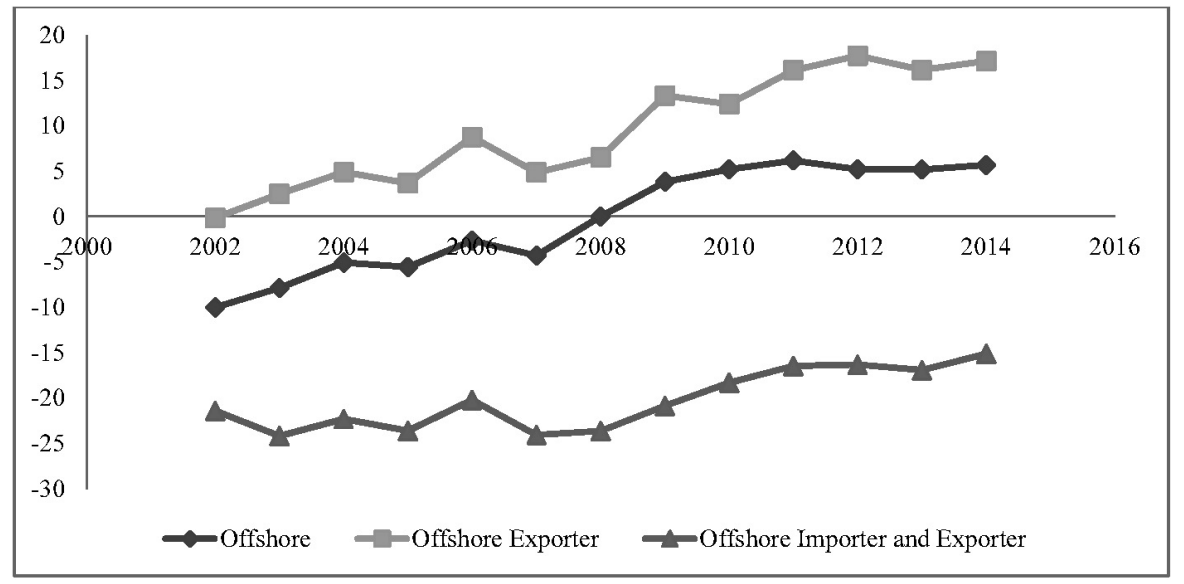

(Source) Authors calculations based on Tunisian Enterprise Survey data (Répertoire National des Entreprises) from the National Institute of Statistics

\section{Survival Analysis}

A regulation's success can be assessed through the benefits that emerge after its implementation. Examples of this are the offshore premia shown above. Another way to evaluate the efficiency of a measure is to determine its impact on the survival of firms. In this section, we investigate whether financial incentives offered to offshore firms influence their survival.

Building on the small number of recent empirical studies that examine the relationship between international trade and firm survival (Baldwin and Yan 2011, Namini, Facchini, and Lopez 2013), we estimate the following probit model:

$$
\operatorname{Pr}\left(\text { Exit }_{i, t+1}=1\right)=\Phi\left(\delta_{0}+\rho T S_{i}+\tau(\text { Age }>9)_{i t} \times T S_{i}+\sigma V i t+\mu_{k}+\varepsilon_{j}+\varepsilon_{t}+v_{i t}\right.
$$

The analysis focuses on the one-year survival rate. Exit $t_{i, t+1}$ takes the value 1 if firm $i$ exits the market at year $t+1$ and 0 if it does not exit (i.e., it survives). $\Phi$ is the standard normal cumulative function. $T S_{i t}$ is a dummy variable representing the trade status of the firm in year $t$. In Column (7a), this dummy equals 1 for offshore firms and 0 for onshore firms. In Columns (7b) and (7c), the dummy equals 1 if the firm is an offshore exporter, 0 if it is an onshore exporter, and equals 1 if the firm is an offshore exporter and importer, and 0 if it is an onshore exporter and importer. We combine this trade status variable with another dummy variable, Age $>9$, to determine whether the end of offshore tax privileges, which takes place when a firm is 10-years old, influences the survival of a firm. $V_{i t}$ is a vector of standard firm characteristics that includes the characteristics outlined in Equation 1 (i.e., size as represented 
by number of employees, and a dummy controlling for tax evasion). $\mu_{k}$ controls for a governoratespecific effect, and $\varepsilon_{j}$ and $\varepsilon_{t}$ control for sector and year effects.

Results are reported in Table 6. The positive and significant coefficient on the Trade Status (TS) variable in all cases indicates that the offshore regime increases the probability that a firm will exit (will not survive) compared to the exit probability for onshore firms of the same type. More precisely, an offshore firm is more likely to exit the market within a year, whatever its type (offshore, offshore exporting only, or offshore exporting and importing). This effect is strengthened for importing and exporting offshore firms older than 9 years, but not for firms engaged solely in exporting. This is a reasonable result since offshore exporting and importing firms are the largest beneficiaries of the offshore regime, being exempted from customs duties on their imports in addition to the other privileges common to all kinds of firms. Therefore, they become the most vulnerable when those privileges stop.

When we consider firms engaged solely in exporting, those that appear to be evading taxes (or have reporting anomalies) have a higher probability of exiting the market. In contrast, tax evasion reduces the probability of exiting for firms involved in both exporting and importing. Consistent with the literature, this suggest that larger firms are more likely to survive.

Table 6. Exit probit estimations

\begin{tabular}{lccc}
\hline & & Trade Status & \\
\cline { 2 - 4 } Exit at $t+1$ & All firms & Exporter & Importer and Exporter \\
& $(7 \mathrm{a})$ & $(7 \mathrm{~b})$ & $0.1642^{* * *}$ \\
\hline Intercept & $0.2884^{* * *}$ & $0.1991^{* * *}$ & $(0.0301)$ \\
& $(0.0067)$ & $(0.0353)$ & $0.0343^{* * *}$ \\
Trade Status & $0.0374^{* * *}$ & $0.041^{* * *}$ & $(0.0028)$ \\
& $(0.0021)$ & $(0.0036)$ & $0.0238^{* * *}$ \\
Trade Status $\times$ Age $>9$ & $0.0352^{* * *}$ & $0.0087^{*}$ & $(0.0026)$ \\
& $(0.0028)$ & $(0.0048)$ & $-0.0253^{* * *}$ \\
Tax Evasion & $0.022^{* * *}$ & $0.0395 * * *$ & $(0.0023)$ \\
Ln Employees (size) & $(0.0018)$ & $(0.006)$ & $-0.0305^{* * *}$ \\
& $-0.0644^{* * *}$ & $-0.0546^{* * *}$ & $(0.0007)$ \\
Observations & $(0.0004)$ & $(0.0012)$ & 64868 \\
$R^{2}$ & 676919 & 55505 & 0.0515 \\
\hline
\end{tabular}

(Note) Foreign ownership dummy, governorate, sector and year fixed effects are included. *** $p<0.01 ; * * p<0.05 ; * p<0.1$.

Table 7 considers several cut-off ages for firms, namely three, six, nine, and 12 years (increments of three years). Column (7a) shows that offshore firms are more likely to exit within a year at any of these starting ages, but exits peak when firm age reaches nine years. Three years seems also to be a critical age for firm survival. Column (7b) points out that young offshore firms, those that have been in business for three years, have a higher probability 
of exiting the market. This probability decreases for offshore firms that only export that did not exit at age three. Moreover, firms in that trade category that reached 12 years are less likely to exit than onshore firms that only export.

Interestingly enough, the exit probability of offshore firms engaged in two-way trading compared to onshore two-way trading firms has an inverted $U$ shape (Column (7c)). It attains its maximum when the firm reaches nine years old. It appears that the end of the privileges of tax and tariff exemptions play a role in exiting the market. This result supports our previous findings. Offshore firms engaged in both exporting and importing, which are most likely involved in the offshore assembly trade, are low performers. They cannot afford the high fixed costs associated with exporting. They enter the offshore regime as it allows them to lower those fixed costs with tariff and tax exemptions. Once those privileges end, they exit the market.

Table 7. Exit probit estimations for different ages

\begin{tabular}{lccc}
\hline & \multicolumn{3}{c}{ Trade Status } \\
\cline { 2 - 4 } Exit at $t+1$ & All firms & Exporter & Importer and Exporter \\
& $(7 \mathrm{a})$ & $(7 \mathrm{~b})$ & $(7 \mathrm{c})$ \\
\hline Trade Status $\times$ Age $>3$ & $0.0305^{* * *}$ & $0.0123^{* *}$ & $(0.0055)$ \\
& $(0.0036)$ & $0.0142^{* * *}$ \\
Trade Status $\times$ Age $>6$ & $0.0273^{* * *}$ & $(0.0054$ & $0.0179^{* * *}$ \\
& $(0.0026)$ & $0.0087^{*}$ & $(0.0026)$ \\
Trade Status $\times$ Age $>9$ & $0.0352^{* * *}$ & $(0.0048)$ & $0.0238^{* * *}$ \\
& $(0.0028)$ & $-0.0104 *$ & $(0.0026)$ \\
Trade Status $\times$ Age $>12$ & $0.0273^{* * *}$ & $(0.0057)$ & $0.0141^{* * *}$ \\
\end{tabular}

(Note) Trade Status, Tax evasion, In Employees, Foreign ownership dummy, governorate, sector and year fixed effects are included. $* * * p<0.01 ; * * p<0.05 ; * p<0.1$.

\section{Concluding Remarks}

In this study, we examine the efficiency of the offshore regime that has been in place in Tunisia since 1972. Our results show that offshore firms in general, and offshore firms engaged only in exporting perform better across the board than their onshore counterparts. However, the opposite holds when we consider firms involved in both exporting and importing. In this case, offshore firms underperform their counterparts. Estimates of the offshore premia for the period 2002 2014 support these findings. An initial assessment conducted on the entire sample, including all offshore and onshore firms, shows the former performing better than the latter, with the exception of average wages, which were lower for offshore firms before 2008. The results focusing only on exporting firms are similar to the initial findings and tend to support the notion that offshore firms in general, and offshore exporters significantly outperform their 
onshore counterparts in terms of turnover and productivity. The success of offshore firms and offshore exporters compared to onshore firms and onshore exporters is mainly due to incentives given in the investment code. When comparing firms involved in both exporting and importing, we find different results. Offshore exporting and importing firms perform worse than their onshore counterparts, across all categories considered. Given that offshore exporting and importing firms benefit from the largest share of privileges, this result suggests the exemptions are not helpful for these firms.

Our findings suggest that offshore firms involved in exporting and importing are low performers. They generally engage in processing and pure assembly activities. Their low labor productivity implies that they produce low value-added products. Offshore firms in this category choose to participate in the offshore regime when tariff and tax exemptions allow them to operate with lower fixed export costs; however, when those subsidies end they have a higher probability of exiting the market than onshore firms that both export and import but that had no exemptions. Survival results support this hypothesis. Offshore firms in this category are more likely to exit when financial incentives stop, usually after 10 years.

The policy implications of our results are significant, especially at the present time when the Tunisian government is considering implementing deep reforms. First, our findings support the argument that the incentive-based Tunisian Investment Code helped the country to expand its exports and to integrate into GVCs of labor-intensive sectors including (a) transport equipment, (b) computer, electronic, electrical equipment, machinery and (c) optical products, and textile, clothing, leather and footwear. These firms account for a large portion of the Tunisian economy today. Offshore firms and offshore exporters are superior performers compared to their onshore counterparts across the board. Second, when offshore firms involved in both exporting and importing firms are considered, the incentives appear to be counterproductive to Tunisia's efforts to move up the global value chain. Indeed, it appears that such incentives are attracting low performers that perform pure assembly activities. Offshore firms that both export and import are more likely to simply cease their activities once tax and tariff privileges end. Therefore, Tunisia should consider other ways, among them financial incentives, to reduce barriers to GVCs participation by all firms, not only offshore firms. Tunisia should specifically target high valueadded sectors with a comprehensive package of market reforms that lower regulations, favor innovation and make use of complex skills and capital.

\section{References}

Alvarez, R., and R.A. Lopez. (2005). "Exporting and performance: Evidence from chilean plants." Canadian Journal of Economics 38, 1384-1400. 
Baghdadi, L. (2015). Firms, trade and employment in Tunisia. International Trade Centre Working Paper Series WP-07-2015. E.

Baldwin, J., and B. Yan. (2011). "The death of Canadian manufacturing plants: Heterogeneous responses to changes in tariffs and real exchange rates." Review of World Economics 147, no. 1, 131-167. Bernard, A.B., and J.B. Jensen. (1995). "Exporters, jobs, and wages in U.S. manufacturing: 1976 - 1987." Brookings Papers on Economic Activity, Microeconomics, no. 1, 67-119.

Blalock, G., and P.J. Gertler. (2004). "Learning from exporting revisited in a less developed setting." Journal of Development Economics 75, 397-416.

Clerides, S.K., S. Lach, and J.R. Tybout. (1998). "Is learning by exporting important? Micro-dynamic evidence from Colombia, Mexico, and Morocco." Quarterly Journal of Economics 113, no. 3, 903-947.

Dai, M., M. Maitra, and M. Yu. (2016). "Unexceptional exporter performance in China? The role of processing trade." Journal of Development Economics 121, 177-189.

Economic Policy Analysis. (2012). Tunisie- Cô̂t-bénéfice des incitations fiscales et financières à l'investissement.

Haidar, J.I. (2012). "Trade and productivity: Self-selection or learning-by-exporting in India?" Economic Modelling 29, 1766-1773.

Iacovone, L., and B. Javorcik. (2012). Getting ready: preparation for exporting. Centre for Economic Policy Research Discussion Papers 8926.

Kasahara, H., and B. Lapham. (2013). "Productivity and the decision to import and export: Theory and evidence." Journal of International Economics 89, no. 2, 297-316.

Kraay, A. (2002). "Exports and economic performance: Evidence from a panel of Chinese enterprises." In China and its Regions, edited by Mary-Francoise Renard, 278-299. Cheltenham: Edward Elgar.

Namini, J.E., G. Facchini, and R. Lopez. (2013). "Export growth and firm survival.” Economics Letters 120, no. 3, 481-486.

Organisation for Economic Cooperation and Development. (2013). Analysis of the Tunisian Tax Incentives Regime. Paris.

Organisation for Economic Cooperation and Development. (2014). L'investissement en faveur de la montée en gamme de la Tunisie dans les chaines de valeur mondiales. Paris.

Répertoire National des Entreprises (RNE), National Institute of Statistics. http://www.ins.nat.tn/

Rijkers, B., H. Arouri, C. Freund, and A. Nucifora. (2014). "Which firms create the most jobs in developing countries? evidence from Tunisia." Labour Economics 31, 84-102.

Rijkers B., H. Arouri, and L. Baghdadi. (2017). "Are politically connected firms more likely to evade taxes? evidence from Tunisia." The World Bank Economic Review 30, Supplement_1, S166-175.

Rodrik, D. (2004). "Industrial policy for the twenty-first century." Harvard University.

Serti, F., C. Tomasi, and A. Zanfei. (2010). "Who trades with whom? Exploring the links between firms' International Activities, Skills, and Wages." Review of International Economics 18, no. 5, 951-971.

Temouri, Y., A. Vogel, and J. Wagner. (2013). "Self-selection into export markets by business services firms - Evidence from France, Germany and the United Kingdom." Structural Change and Economic Dynamics 25, no. C, 146-158.

Wagner, J. (2013). "Exports, imports and firm survival: First evidence for manufacturing enterprises in 
Germany." Review of World Economics 149, no. 1, 113-130.

Wagner, J. (2012). "International trade and firm performance: A survey of empirical studies since 2006." Review of World Economics 148, no. 2, 235-267.

Wang, J. (2013). "The economic impact of special economic zones: Evidence from Chinese municipalities." Journal of Development Economics 1015, no. C, 133-147.

Yang, Y., and S. Mallick. (2010). "Export premium, self-selection and learning -by-exporting: Evidence from Chinese matched firms." The World Economy 33, no. 10, 1218-1240. 


\section{Appendix 1. Data Definition}

\begin{tabular}{|c|c|}
\hline Variable & Definition \\
\hline Turnover & Annual sales \\
\hline Productivity & Real gross output per worker \\
\hline Wages & Average annual wage per worker \\
\hline Trade Status & $\begin{array}{l}\text { Dummy with value }=1 \text { if the firm is offshore, offshore-only exporting or offshore exporting and } \\
\text { importing, } 0 \text { if it is onshore, onshore-only exporting or onshore exporting and importing, } \\
\text { depending on the specification }\end{array}$ \\
\hline Age & Age of the firm \\
\hline Size & Number of employees $(\log )$ \\
\hline Tax Evasion & $\begin{array}{l}\text { Dummy variable with value }=1 \text { if the firm is likely to evade taxes, } 0 \text { otherwise. The firm is most } \\
\text { likely to avoid taxes if sales reported to the social security administration are lower than (i) } \\
\text { the wage bill reported to the social security administration (ii) total exports or (iii) total imports } \\
\text { recorded in customs transactions data }\end{array}$ \\
\hline Exit $_{i, t+1}$ & Dummy variable with value $=1$ if firm $I$ exits the market at year $t+l$ and 0 if not \\
\hline Foreign ownership & Dummy variable with value $=1$ if the firm is owned by a foreigner \\
\hline
\end{tabular}

\section{Appendix 2. Descriptive Statistics for 2014}

\begin{tabular}{|c|c|c|c|c|c|c|}
\hline Trade Status & \# firms & Variable & $\mathrm{N}$ & Sum & Mean & Std Dev \\
\hline \multirow[t]{3}{*}{ Onshore } & \multirow[t]{3}{*}{620235} & lnTurnover & 432,979 & $5,250,509$ & 12,13 & 1,91 \\
\hline & & InProductivity & 432,911 & $4,665,763$ & 10,78 & 1,37 \\
\hline & & InAverage Wage & 613,715 & $5,030,264$ & 8,20 & 0,63 \\
\hline \multirow[t]{3}{*}{ Offshore } & \multirow[t]{3}{*}{56684} & lnTurnover & 48,179 & 635,686 & 13.19 & 1.91 \\
\hline & & InProductivity & 48,173 & 495,789 & 10.29 & 1.76 \\
\hline & & lnAverageWage & 56,318 & 471,239 & 8,37 & 0,83 \\
\hline \multirow{3}{*}{$\begin{array}{l}\text { Onshore Sole } \\
\text { Exporters }\end{array}$} & \multirow[t]{3}{*}{37106} & ln Turnover & 35,596 & 444,574 & 12,49 & 1,48 \\
\hline & & InProductivity & 35,592 & 388,086 & 10,90 & 1,23 \\
\hline & & lnAverage Wage & 36,892 & 311,661 & 8,45 & 0,70 \\
\hline \multirow{3}{*}{$\begin{array}{l}\text { Offshore Sole } \\
\text { Exporters }\end{array}$} & \multirow[t]{3}{*}{18399} & lnTurnover & 17,976 & 224,226 & 12,47 & 1,77 \\
\hline & & InProductivity & 17,973 & 189,585 & 10,55 & 1,88 \\
\hline & & lnAverage Wage & 18,244 & 157,280 & 8,62 & 0,94 \\
\hline \multirow{3}{*}{$\begin{array}{l}\text { Onshore Exporters } \\
\text { and Importers }\end{array}$} & \multirow[t]{3}{*}{32349} & InTurnover & 30,610 & 444,242 & 14,51 & 1,72 \\
\hline & & InProductivity & 30,609 & 353,481 & 11,55 & 1,24 \\
\hline & & lnAverage Wage & 32,277 & 282,044 & 8,74 & 0,69 \\
\hline \multirow{3}{*}{$\begin{array}{l}\text { Offshore Exporters } \\
\text { and Importers }\end{array}$} & \multirow[t]{3}{*}{32519} & lnTurnover & 29,726 & 405,941 & 13,66 & 1,84 \\
\hline & & InProductivity & 29,723 & 301,548 & 10,15 & 1,67 \\
\hline & & lnAverage Wage & 32,418 & 267,183 & 8,24 & 0,69 \\
\hline
\end{tabular}




\section{Appendix 3. Robustness Checks}

\section{A. Impact of the financial crisis of 2008 2009 on firms' performance}

\section{Specification}

Onshore and offshore firms are different in terms of market orientation, i.e., domestic versus international markets, and paths of internationalization. Onshore firms focus first on serving local markets. Most productive onshore firms will gradually increase their international involvement over time. Offshore firms have a different approach. By choosing the offshore regime, they are bound by law to serve only international (non-domestic) markets. These are generally processing firms that are able to integrate into GVCs. These different strategies make these two types of firms barely comparable. Thus, the choice of which regime in which to operate is clearly endogenous. To deal with this issue, we wish to identify how both types of firms respond to shocks in the economy. To this end, we assess the impact of the financial crisis of 2008 2009 on both onshore and offshore firms. This crisis undoubtedly impacted the decline in external demand for Tunisian exports given that most Tunisian products are exported to European countries.

We use the following specification to evaluate the effect of the TS variable on firms' performance:

$$
\ln Y_{i t}=\alpha+\beta_{1} T S_{i t}+\beta_{2}\left(\text { post }_{t}^{*} T S_{i t}\right)+\beta_{3} X_{i t}+\beta_{4} \text { post }_{t}^{*} X_{i t}+\delta_{1_{t g}}+\delta_{2 s}+\delta_{3 t}+\epsilon_{i t}
$$

Where $i$ and $t$ index the firms and time, respectively. $Y_{i t}$ represents the firm's yearly performance such as turnover, productivity or wages. $T S_{i}$ represents the firm's TS (offshore or onshore, offshore-only exporter or onshore-only exporter, offshore exporter and importer or onshore exporter and importer, depending on the specification). We define the dummy variable post $_{t}$ as taking the value of 1 after 2009. We combine firms' TS with post to evaluate the impact of the 2008 2009 financial crisis on offshore firms compared to onshore firms, depending on their TS. $X_{i t}$ represents a control of certain observable features of the firms at a given time (size, proxied by the number of employees, foreign ownership and tax evasion). The coefficient $\beta_{4}$ represents the crisis' effect on offshore firms compared to onshore ones, depending on their TS. $\delta_{1 g}, \delta_{2 s} \delta_{3 t}$ denotes governorate-specific, sector-specific and time-specific fixed effects. $\epsilon_{i t}$ is an idiosyncratic error term that is assumed to be independent and identically distributed.

\section{Results}

Our results are displayed in Table 3.1. They show that trends for all indicators correspond 
to results from indicators related to the various premia, presented in the body of this paper. Regarding the impact of the crisis of 2008 2009, we observe that it had a more negative impact on offshore firm relative to onshore firms when all firms are considered. This result is likely due to the decline in external demand and confirms our expectations, as offshore firms produce for international markets. However, offshore exporters were particularly resilient during the crisis compared to their onshore counterparts, which may be due to their greater integration into international networks. They performed better with respect to all indicators compared to onshore exporters after the shock of 2008 2009. This difference might also be explained by the fact that offshore exporters have lower fixed costs compared to onshore exporters, as they are often subsidiaries of larger firms. Finally, the decline in external demand impacted offshore and onshore two-way trading firms equally in terms of turnover and productivity.

Larger offshore firms, including all types, were more resilient compared to onshore firms. Foreign ownership appeared to have a positive impact in general on all performance indicators for offshore firms, with all types included. However, foreign ownership had not significant impact on the recovery of those firms after 2009 compared to onshore firms. Finally, the effect of tax discrepancies on performance indicators for offshore firms, including offshore exporters and offshore exporters and importers appear to be less than for to onshore firms. However, tax discrepancies for offshore exporters and importers increased after 2009, which helped them to recover their performance.

Table 3.1. Impact of the financial crisis of 2008 2009 on firms' performance by trade status, all sectors

\begin{tabular}{|c|c|c|c|c|}
\hline & & Offshore & Offshore Exporters & $\begin{array}{l}\text { Offshore Exporters } \\
\text { and Importers }\end{array}$ \\
\hline \multirow[t]{16}{*}{ ln Turnover } & \multirow[t]{2}{*}{ Trade Status } & $0.4086^{* * *}$ & $0.1217 * * *$ & $-0.2895 * * *$ \\
\hline & & $(0.0123)$ & $(0.0206)$ & $(0.0205)$ \\
\hline & \multirow[t]{2}{*}{ Post2009*Trade Status } & $-0.0892 * * *$ & $0.0816^{* * *}$ & -0.0098 \\
\hline & & $(0.0154)$ & $(0.0245)$ & $(0.0255)$ \\
\hline & \multirow[t]{2}{*}{ InEmployees } & $1.0699 * * *$ & $0.7872 * * *$ & $0.8402 * * *$ \\
\hline & & $(0.0019)$ & $(0.0056)$ & $(0.0044)$ \\
\hline & \multirow[t]{2}{*}{ Post2009*InEmployees } & $0.1505^{* * *}$ & $0.1062 * * *$ & $0.0865^{* * *}$ \\
\hline & & $(0.0018)$ & $(0.0053)$ & $(0.0039)$ \\
\hline & \multirow[t]{2}{*}{ Evasion } & $-1.2407 * * *$ & $-1.8721^{* * *}$ & $-0.6597 * * *$ \\
\hline & & $(0.0125)$ & $(0.039)$ & $(0.019)$ \\
\hline & \multirow[t]{2}{*}{ Post2009*Evasion } & $-0.2458^{* * *}$ & -0.0512 & $0.0838 * * *$ \\
\hline & & $(0.0164)$ & $(0.05)$ & $(0.0264)$ \\
\hline & \multirow[t]{2}{*}{ Foreign ownership } & $0.3124 * * *$ & $0.2046^{* * *}$ & $0.1692 * * *$ \\
\hline & & $(0.0154)$ & $(0.0296)$ & $(0.0206)$ \\
\hline & \multirow[t]{2}{*}{ Post2009*Foreign ownership } & -0.0055 & -0.0447 & $0.0924 * * *$ \\
\hline & & $(0.0204)$ & $(0.0361)$ & $(0.0281)$ \\
\hline
\end{tabular}


Table 3.1. Continued

\begin{tabular}{|c|c|c|c|c|}
\hline & & Offshore & Offshore Exporters & $\begin{array}{c}\text { Offshore Exporters } \\
\text { and Importers }\end{array}$ \\
\hline \multirow[t]{16}{*}{ In Productivity } & \multirow[t]{2}{*}{ Trade Status } & $0.411 * * *$ & $0.1209 * * *$ & $-0.2787 * * *$ \\
\hline & & $(0.012)$ & $(0.0202)$ & $(0.0204)$ \\
\hline & \multirow[t]{2}{*}{ Post $2009 *$ Trade Status } & $-0.0735 * * *$ & $0.0968 * * *$ & -0.0063 \\
\hline & & $(0.015)$ & $(0.024)$ & $(0.0253)$ \\
\hline & \multirow[t]{2}{*}{ InEmployees } & $-0.0876^{* * *}$ & $-0.3709 * * *$ & $-0.2367 * * *$ \\
\hline & & $(0.0019)$ & $(0.0055)$ & $(0.0044)$ \\
\hline & \multirow[t]{2}{*}{ Post $2009 * \ln E m p l o y e e s$} & $0.1445 * * *$ & $0.1003^{* * *}$ & $0.0864 * * *$ \\
\hline & & $(0.0018)$ & $(0.0052)$ & $(0.0039)$ \\
\hline & \multirow[t]{2}{*}{ Evasion } & $-1.1742 * * *$ & $-1.8235^{* * *}$ & $-0.6422 * * *$ \\
\hline & & $(0.0122)$ & $(0.0382)$ & $(0.0189)$ \\
\hline & \multirow[t]{2}{*}{ Post2009*Evasion } & $-0.279 * * *$ & -0.0452 & $0.0745^{* * *}$ \\
\hline & & $(0.016)$ & $(0.0491)$ & $(0.0262)$ \\
\hline & \multirow[t]{2}{*}{ Foreign ownership } & $0.3219 * * *$ & $0.2262 * * *$ & $0.1723^{* * *}$ \\
\hline & & $(0.0151)$ & $(0.029)$ & $(0.0205)$ \\
\hline & \multirow{2}{*}{ Post2009*Foreign ownership } & 0.0009 & -0.0533 & $0.0886^{* * *}$ \\
\hline & & $(0.0199)$ & $(0.0354)$ & $(0.0279)$ \\
\hline \multirow[t]{16}{*}{ In Average Wage } & \multirow[t]{2}{*}{ Trade Status } & $0.0543 * * *$ & 0.0118 & $-0.2885 * * *$ \\
\hline & & $(0.0051)$ & $(0.0108)$ & $(0.0088)$ \\
\hline & \multirow[t]{2}{*}{ Post09*Trade Status } & $-0.0547 * * *$ & $0.1631 * * *$ & $0.1523 * * *$ \\
\hline & & $(0.0063)$ & $(0.0129)$ & $(0.011)$ \\
\hline & \multirow[t]{2}{*}{ lnEmployees } & $0.0293 * * *$ & $-0.0158 * * *$ & $0.0291 * * *$ \\
\hline & & $(0.0008)$ & $(0.003)$ & $(0.0019)$ \\
\hline & \multirow[t]{2}{*}{ Post $2009 * \ln E m p l o y e e s$} & $0.1916^{* * *}$ & $0.1347 * * *$ & $0.0901 * * *$ \\
\hline & & $(0.0007)$ & $(0.0028)$ & $(0.0018)$ \\
\hline & \multirow[t]{2}{*}{ Evasion } & $0.0407 * * *$ & -0.0034 & $-0.0547 * * *$ \\
\hline & & $(0.0056)$ & $(0.0209)$ & $(0.0083)$ \\
\hline & \multirow[t]{2}{*}{ Post $2009 *$ Evasion } & $0.0305 * * *$ & $0.1106^{* * *}$ & -0.0011 \\
\hline & & $(0.0068)$ & $(0.0265)$ & $(0.0116)$ \\
\hline & \multirow[t]{2}{*}{ Foreign ownership } & $0.249 * * *$ & $0.2506^{* * *}$ & $0.145 * * *$ \\
\hline & & $(0.0063)$ & $(0.0157)$ & $(0.0089)$ \\
\hline & \multirow[t]{2}{*}{ Post2009*Foreign ownership } & $0.026^{* * *}$ & -0.0055 & $0.0563 * * *$ \\
\hline & & $(0.0084)$ & $(0.0191)$ & $(0.0123)$ \\
\hline
\end{tabular}

(Note) $* * * p<0.01 ; * * p<0.05 ; * p<0.1$

Governorate, sector and time fixed effects are included in all regressions

\section{B. Controlling for restrictions of entry}

The concentration of the offshore sector in labor-intensive industries might be explained by regulatory barriers to entry for more capital-intensive industries. As a way to proxy entry 
restrictions, we run a test which consists of adding a dummy controlling for firms connected to former Tunisian President Ben Ali and his family. Ben Ali firms are generally concentrated in highly regulated sectors. The period considered begins in 2002 and ends with the Tunisian revolution and the end of Ben Ali's reign, i.e., 2011.

Results in Table 3.2 are similar to those shown in Table 3, thus confirming their robustness. 


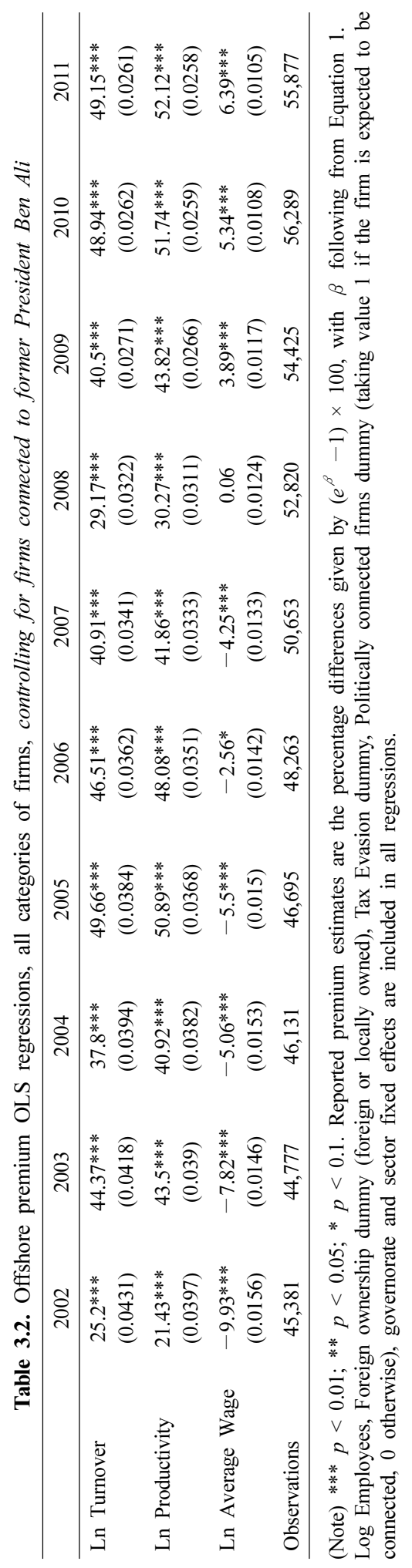

